International Journal of Education and Practice

2021 Vol. 9, No. 1, pp. 128-140.

$\operatorname{ISSN}(e): 2310-3868$

$\operatorname{ISSN}(p): 2311-6897$

DOI: 10.18488/journal.61.2021.91.128.140

(C) 2021 Conscientia Beam. All Rights Reserved.

check for

\title{
CRITICAL REVIEW ON FLIPPED CLASSROOM MODEL VERSUS TRADITIONAL LECTURE METHOD
}

\author{
Saira ${ }^{1+}$ \\ Fouzia Ajmal $^{2}$ \\ (iD) Muhammad \\ Hafeez $^{3}$
}

\author{
${ }^{\prime}$ Department of Education, University of Gujarat, Gujarat, Pakistan. \\ Email:saira.usman@uog.edu.pk Tel:+92-321626095s \\ ${ }^{2}$ Department of Education, International Islamic University, Islamabad, \\ Pakistan. \\ Email:fouria.ajmal@izu.edu.pk Tel:+92-3365413721 \\ ${ }^{3}$ Research Scholar, Allama Iqbal Open University, Islamabad, Pakistan. \\ Email:129589041@gmail.com Tel: +92-3356727430
}

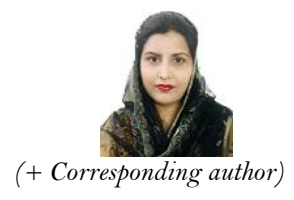

Article History

Received: 26 November 2020 Revised: 28 December 2020 Accepted: 19 January 2021 Published: 24 February 2021

\section{Keywords}

Flipped classroom model

Learning strategy

Technology

Teaching

Traditional method.

\begin{abstract}
Flipped classroom model is now a well-established learning approach which has brought a paradigm shift by blending technology with the traditional method of teaching. The real meaning of Flipped classroom model is that the traditional lecture method is flipped so that learners get the initial learning material at home and class time is used for cooperative learning. The tools used for the flipped classroom model include Learning management system, social media and like. A lot of research studies exist on Flipped classroom model but these studies lack a unified approach over its significance. If one set of studies ranks Flipped classroom model better than the traditional lecture method; the other instruction models consider its success due to its integration with technology. There are also studies that associate Flipped classroom model with student-centered approach especially in university education. This article reviews a few of these studies with the objective to understand this debate about the right method of learning; and to identify which studies acknowledge the significance of Flipped classroom model. A set of 33 articles published from 2012 to 2020 were selected for this study. The statistical results show a mixed reaction about the acceptability and adaptability of the Flipped classroom model in the modern learning environment.
\end{abstract}

Contribution/Originality: This study makes a critical review of 33 studies on Flipped classroom model with the view to understand how the previous studies have acknowledge the importance, adaptability and of flipped classroom model in the modern learning environments and also how they differentiated this model from the Traditional Lecture Method.

\section{INTRODUCTION}

Learning is an essential element of humankind and crucial for the development of a nation (Hafeez et al., 2020). Buckman et al. (2010) stated that there are four important strategies for active learning (1) create individual activities in and out of the classroom (2) integrate students in group activities (3) inspire informal group, and (4) assign project tasks to cooperative students. Engaging these concepts with "Flipped classroom model" involves students to take part in the learning process with full concentration. This model enables students to learn more cooperatively and think critically. It also allows students to share their knowledge with peers (Michel, Cater III, \& Varela, 2009). The Flipped classroom model improves the efficacy of learning and increases the motivation level of 
students to learn actively (Lewis, Chen, \& Relan, 2018). The Flipped classroom model of instruction was established by Bergmann and Sams (2012) to deliver lecture to students of secondary schools who had not taken all the classes. In the Flipped classroom instruction model, work is done by the students prior to a class. The Bloom's taxonomy related to traditional and flipped learning approaches is shown in Figure 1.

Traditional Classroom

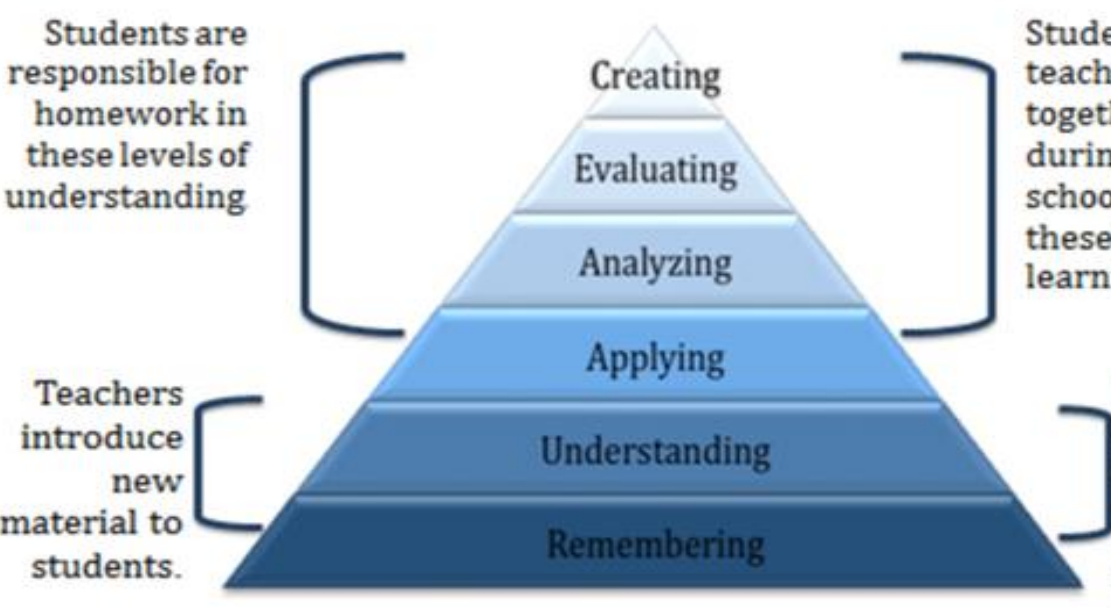

Figure-1. Bloom's taxonomy related to traditional and flipped learning approaches.
Flipped Classroom

The researches indicate that in Flipped classroom model of instruction, the learners actively participate and achieve better conceptual learning as compared to other traditional lecture methods (Sezer, 2010). Roehl, Reddy, and Shannon (2013) stated the Flipped classroom instruction model can be easily integrated with technology before the class and the class time can be used for active and cooperative learning. The Flipped classroom model also applies student-centered approach for learning process (Abeysekera \& Dawson, 2015). Flipped classroom model is getting more attention in educational activities specially in university education (Toppo, 2011). In Flipped classroom model, the traditional lecture method is flipped so that learners get the initial learning material at home and class time is used for cooperative learning. The tools used for the flipped classroom model include Learning management system, YouTube, WhatsApp (Pohl, Bouchachia, \& Hellwagner, 2018).

\subsection{Flipped Classroom Learning or Blended Learning}

Graham, Woodfield, and Harrison (2013) suggested that in blended learning, face to face and computer-based instructions are mixed. The Flipped classroom model of learning is based on online video and audio lectures provided out of the class and the problem-solving discussion sessions are conducted in the classroom. The blended learning is type of learning in which mixed teaching strategy (traditional and information technology) is provided to learners. The blended learning is therefore also called Flipped classroom model of learning (Staker \& Horn, 2012).

The comparison between the traditional classroom and Flipped classroom in achieving higher order thinking skills in Blooms Taxonomy is stated in Table 1. There are three levels of learning in traditional lecture and flipped classroom model of instruction. For remembering learning level, face to face learning happens in traditional classroom while pre-recorded lecture and videos are used for the learning process. For understanding learning level, Question and answer tools are used in traditional classroom and peer to peer discussion tools are used in flipped classroom for understanding learning level. For analyzing understanding level of learning, homework tool is used in traditional lecture classroom while in flipped classroom, projects and presentation tools are used. 
Table-1. Comparison of traditional and flipped classroom in blooms taxonomy.

\begin{tabular}{l|l|l}
\hline Level of Learning & Traditional Classroom Tools & Flipped Classroom Tools \\
\hline Remembering & Face to face lecture & $\begin{array}{l}\text { Pre-recorded lectures, reading material and } \\
\text { watching video lectures independently }\end{array}$ \\
\hline Understanding & Question and answer & $\begin{array}{l}\text { Reflection, Peer-to-peer discussion and } \\
\text { collaboration }\end{array}$ \\
\hline Analyzing & Classroom activities such as group discussion \\
\hline $\begin{array}{l}\text { Applying, Evaluating, } \\
\text { Creating }\end{array}$ & Homework & $\begin{array}{l}\text { Student projects, presentations and instructor } \\
\text { evaluation }\end{array}$ \\
\hline
\end{tabular}

Table 2 shows that how traditional and Flipped classroom instructional methods are demonstrated according to the classroom time management stated by Bergmann and Sams (2012). The classroom activities in both traditional and flipped classroom models of instruction are distributed in various time steps. In traditional lecture method, the warm up activity is done for 5 minutes, previous homework is revised for 20 minutes, the new content is delivered for 30-45 minutes and Guided and independent practice and active learning is done for 20-35 minutes. In Flipped Classroom model of Instruction, the warm up activity is done for 5 minutes, Questions and Answering on video lecture is performed for 10 minutes and Guided and independent practice and active learning is done for 75 minutes.

Table-2. Traditional and Flipped Classroom activities based on Bergmann and Sams, (2012).

\begin{tabular}{l|c|l|c}
\hline Traditional classroom & \multicolumn{2}{c}{ Flipped classroom } \\
\hline Activity & Time $(\mathrm{min})$ & Activity & Time $(\mathrm{min})$ \\
\hline Activity to warm up & 5 & Activity to warm up & 5 \\
\hline Go through for previous work & 20 & $\begin{array}{l}\text { Questions and Answers } \\
\text { on video lectures }\end{array}$ & $\begin{array}{l}\text { Active learning and } \\
\text { independent practice }\end{array}$ \\
\hline New content lecture & $30-45$ & & 75 \\
\hline Active learning and independent practice & $20-35$ & & \\
\hline
\end{tabular}

Bishop and Verleger (2013) suggested that the interaction with teacher during learning process is less significant during instructions as compared to real life problem solving based, discussion based, and inquiry-based learning. The Flipped Classroom instruction method exploits on this peculiarity.

\subsection{Significance of Flipped Classroom as an Active Learning Approach}

The effectiveness of Flipped classroom model of instruction has been proved in many studies as an active learning strategy (Kim, Jin, \& Lim, 2015; Park \& Park, 2018; Wilson, 2020).

These studies have discussed flipped classroom as an important part of the paradigm shift from teachercentered to student-centered learning, in which teachers move the knowledge delivery outside of formal class time. In formal class time, students actively and extensively interact with teachers and peers through collaborative work such as "whole-class brainstorming, group-based hands-on assignments and peer-review, feedback exchange and remedial help” (Missildine, Fountain, Summers, \& Gosselin, 2013).

The Flipped Classroom model of instruction highlights the priority of Problems-Solving method over the lecture or traditional teaching method in a classroom. The learning approaches like project-based learning, studentcentered learning, problem-based learning and inquiry-based learning emphasize on students to participate actively in the learning process. Most of these learning approaches use Flipped classroom model of instruction (Grant, 2013; Keengwe \& Bhargava, 2014).

\subsection{Purpose of This Study}

A lot of studies have been conducted on the evaluation of the effectiveness of Flipped classroom model of instruction and traditional lecture method, but there is still little unanimity and consensus regarding the most 
effective methods. The results of previous studies are divergent. There have been many studies including (Bernard, 2015; Chen et al., 2018; Gillette et al., 2018; Hew \& Lo, 2018; Miles \& Fogget, 2016) which examine Flipped Classroom model as more effective, less effective or making no significance differences. The purpose of current study therefore was to review the previous literature about flipped classroom model and traditional lecture method and to compare the results statistically.

\section{REVIEW OF LITERATURE}

It has been a practice that instructors use the traditional lecture method in their classrooms and students follow up lecture with homework (Abedi, Keshmirshekan, \& Namaziandost, 2019). The traditional lecture method makes learners passive in getting knowledge as compared to Flipped classroom model as it makes creators. Knowledge becomes viable when there is dynamic participation in the learning process and communications happen between the components of learning practice (Abedi et al., 2019).

Many researchers including (Ash, 2012; Shakibaei, Namaziandost, \& Shahamat, 2019) stated that a lot of instructors have moved away from traditional lecture methods. In traditional learning method, the learners are required to just submissively attend and listen to teacher's lecture and then gather facts from the notes. This method of teaching has been exposed to be unproductive for learners in present era (Abedi et al., 2019; Brunsell \& Horejsi, 2013). Positive results have been stated by those teachers who have assimilated the Flipped classroom model. The Learners were noted to be more active solving the real-life problems (Lai \& Hwang, 2016; Roach, 2014). It is stated that students were involved in self-learning procedure in Flipped classrooms model (Sohrabi \& Iraj, 2016).

Hew and Lo (2018) conducted 28 revisions equating the flipped classrooms model of instruction to the traditional method of teaching in Nursing. The statistical results show that Flipped classroom model has a $0.33 \%$ more significant value than the traditional lecture-based classroom.

Chen et al. (2018) reviewed 46 empirical researches in the field of non-health and health contexts. Their conclusion was that Flipped classroom model has a $0.47 \%$ more significant value than traditional lecture based classroom.

Gillette et al. (2018) acknowledged five revisions in the perspective of medicinal education and concluded that there is no significant relation between the flipped classrooms model of instruction and traditional lecture method on last examination grades.

\subsection{Flipped Classroom Model of Instruction and Students' Academic Achievements}

In current era, several researches have concentrated on the influences of flipped classrooms model of learning on academic achievements of learners.

Zengin (2017) conducted a research to create Flipped classroom learning environment in Khan Academy and by using an open source mathematical software. The objectives of this research were to inspect the impacts of flipped classrooms model of instruction on academic achievements of students and expose the opinions about the application of flipped classrooms model of instruction. There were 28 participants in research in the subject of Mathematics. The conclusions of the study showed that the flipped classrooms model environment created by Mathematical software and Khan Academy increased students' academic achievements two times more than that of the traditional lecture method.

Zhonggen and Guifang (2016) directed an investigation to explore the efficiency of Flipped classrooms model on English reading and writing courses by using mix method approach. The data was collected on the bases of satisfaction, a test on Business English course and interview. The results of the study showed that members used flipped classrooms model and scored higher grades than the members taught by traditional lecture method. To demonstrate the efficiency of the flipped classroom Model of learning, Janotha (2016) inspected the level to which 
flipped classrooms model affected students' academic achievements in a nursing program. The consequences of the revision exposed that the learners who were taught with Flipped classrooms model scored higher grades as compared to the students taught by traditional lecture method.

A qualitative study about flipped classroom model and traditional lecture method was conducted by O'Flaherty and Phillips (2015). The video lectures were used for the flipped classroom learning process. The results of the study concluded that in flipped classroom model learning strategy, the students achieved higher grades and actively participated in the learning process as compared to the traditional learning method.

The results of the studies reviewed in this study are illustrated in Table 3 and 4.

Table-3. Results of studies reviewed in this article.

\begin{tabular}{|c|c|c|c|}
\hline Reference & Class & Subject & Outcomes \\
\hline $\begin{array}{l}\text { Pierce, Fox, } \\
\text { and Dunn } \\
(2012)\end{array}$ & Undergraduate & Pharmacotherapy & $\begin{array}{l}\text { Flipped classroom model proved better performance than } \\
\text { traditional lecture method. }\end{array}$ \\
\hline $\begin{array}{l}\text { Tune, } \\
\text { Sturek, and } \\
\text { Basile (2013) }\end{array}$ & $\begin{array}{l}\text { First-year } \\
\text { graduate }\end{array}$ & $\begin{array}{l}\text { Cardiovascular, } \\
\text { Respiratory and } \\
\text { Renal Physiology }\end{array}$ & $\begin{array}{l}\text { The students scored higher results by Flipped classroom } \\
\text { model of instruction as compared to the traditional } \\
\text { lecture method. }\end{array}$ \\
\hline Cabı (2018) & $\begin{array}{l}\text { Pre-service } \\
\text { Teachers }\end{array}$ & Computer course & $\begin{array}{l}\text { No significant difference has been found in the scores } \\
\text { taught by flipped classroom model of instruction and } \\
\text { traditional lecture method. }\end{array}$ \\
\hline $\begin{array}{l}\text { Keengwe } \\
(2014)\end{array}$ & 11 Grade & $\begin{array}{l}\text { Advanced } \\
\text { English language } \\
\text { course }\end{array}$ & $\begin{array}{l}\text { The flipped classroom model of instruction showed more } \\
\text { performance as compared to the traditional lecture } \\
\text { method. }\end{array}$ \\
\hline $\begin{array}{l}\text { Overmyer } \\
(2014)\end{array}$ & $\begin{array}{l}\text { College } \\
\text { students }\end{array}$ & Algebra course & $\begin{array}{l}\text { No statistically significance difference in the scores of } \\
\text { students have been found in two groups followed the } \\
\text { flipped classroom model and traditional lecture method } \\
\text { but the students learnt by flipped classroom model of } \\
\text { instruction got slightly better scores. }\end{array}$ \\
\hline $\begin{array}{l}\text { Aidinopoulo } \\
\text { u and } \\
\text { Sampson } \\
(2017)\end{array}$ & $\begin{array}{l}\text { Primary school } \\
\text { students }\end{array}$ & History course & $\begin{array}{l}\text { The conclusion of the study showed that Flipped } \\
\text { classroom instructional model has slightly more learning } \\
\text { outcomes than the traditional learning strategy. }\end{array}$ \\
\hline $\begin{array}{l}\text { Smallhorn } \\
(2017)\end{array}$ & $\begin{array}{l}\text { Second year } \\
\text { college students }\end{array}$ & $\begin{array}{l}\text { Genetics and } \\
\text { Biodiversity } \\
\text { course }\end{array}$ & $\begin{array}{l}\text { The conclusion of the study indicated that the students } \\
\text { actively participated in the learning activities by Flipped } \\
\text { classroom model of instruction. }\end{array}$ \\
\hline $\begin{array}{l}\text { Kostaris, } \\
\text { Stylianos, } \\
\text { Sampson, } \\
\text { Giannakos, } \\
\text { and } \\
\text { Pelliccione } \\
(2017)\end{array}$ & $\mathrm{K}-12$ & ICT Studies & $\begin{array}{l}\text { The learners performed better in flipped classroom } \\
\text { learning strategy. The study also proved that } \\
\text { amalgamation of Flipped classroom model in teaching- } \\
\text { learning process produced significant increase in } \\
\text { cognitive ability of the students. }\end{array}$ \\
\hline $\begin{array}{l}\text { Olakanmi } \\
(2017)\end{array}$ & $\begin{array}{l}\text { Secondary } \\
\text { school students }\end{array}$ & Chemistry & $\begin{array}{l}\text { The findings of the study revealed that the flipped } \\
\text { classroom model produced better results in teaching } \\
\text { learning strategy. The students actively participate in } \\
\text { flipped classroom strategy as compared to the traditional } \\
\text { method of learning. }\end{array}$ \\
\hline Nouri (2016) & $\begin{array}{l}\text { Last year } \\
\text { undergraduate } \\
\text { students }\end{array}$ & $\begin{array}{l}\text { Course in } \\
\text { research methods }\end{array}$ & $\begin{array}{l}\text { The conclusion of the study showed that the most of the } \\
\text { students had positive effect towards Flipped classroom } \\
\text { model of instruction. }\end{array}$ \\
\hline $\begin{array}{l}\text { Morgan et } \\
\text { al. }(2015)\end{array}$ & $\begin{array}{l}\text { Undergraduate } \\
\text { medical student }\end{array}$ & $\begin{array}{l}\text { Gynecology } \\
\text { oncology }\end{array}$ & $\begin{array}{l}\text { The results of the study indicated that incorporation of } \\
\text { flipped classroom model has significantly increased the } \\
\text { student's engagement and achievement. }\end{array}$ \\
\hline $\begin{array}{l}\text { Ayçiçek and } \\
\text { Yanpar } \\
\text { Yelken } \\
(2018)\end{array}$ & $\begin{array}{l}\text { Secondary } \\
\text { school students }\end{array}$ & English & $\begin{array}{l}\text { The study concluded that a statistical significant } \\
\text { difference had been observed in Pre-test and Post-test } \\
\text { scores of experimental group and significant difference } \\
\text { had been observed in Pre-test and Post-test scores of } \\
\text { control group. }\end{array}$ \\
\hline
\end{tabular}




\begin{tabular}{|c|c|c|c|}
\hline $\begin{array}{l}\text { Ahmad } \\
(2016)\end{array}$ & $\begin{array}{l}\text { 3rd-Year } \\
\text { undergraduate } \\
\text { students }\end{array}$ & $\begin{array}{l}\text { English as a } \\
\text { Foreign } \\
\text { Language }\end{array}$ & $\begin{array}{l}\text { It is concluded that the Flipped classroom model of } \\
\text { instruction has statistical significant impact on listening } \\
\text { ability in comprehensive study. }\end{array}$ \\
\hline $\begin{array}{l}\text { Namaziando } \\
\text { st and } \\
\text { Cakmak } \\
(2020)\end{array}$ & $\begin{array}{l}\text { Intermediate } \\
\text { class }\end{array}$ & English & $\begin{array}{l}\text { The results of the study indicated that the experimental } \\
\text { group performed better that was followed by Flipped } \\
\text { classroom model of instruction. }\end{array}$ \\
\hline $\begin{array}{l}\text { Lee and Lai } \\
(2017)\end{array}$ & $\begin{array}{l}\text { secondary } \\
\text { school students }\end{array}$ & ICT course & $\begin{array}{l}\text { The results of the research indicated that by } \\
\text { incorporating technology like Flipped classroom model of } \\
\text { instruction in the learning process, it is possible to } \\
\text { increase the learning abilities of students and higher } \\
\text { order thinking skills. }\end{array}$ \\
\hline $\begin{array}{l}\text { Gillispie } \\
(2016)\end{array}$ & $\begin{array}{l}\text { Undergraduate } \\
\text { students }\end{array}$ & $\begin{array}{l}\text { obstetrics and } \\
\text { gynecology } \\
\text { courses }\end{array}$ & $\begin{array}{l}\text { The students taught by Flipped classroom model of } \\
\text { instruction scored better performance as compared to the } \\
\text { traditional lecture method. }\end{array}$ \\
\hline $\begin{array}{l}\text { Baytiyeh } \\
(2017)\end{array}$ & $\begin{array}{l}\text { Engineering } \\
\text { students }\end{array}$ & $\begin{array}{l}\text { Dynamics of } \\
\text { Structures course }\end{array}$ & $\begin{array}{l}\text { The conclusion of the study confirmed the previous } \\
\text { results about the Flipped classroom model and traditional } \\
\text { lecture method that Flipped classroom is better than the } \\
\text { traditional lecture method. }\end{array}$ \\
\hline $\begin{array}{l}\text { Afrilyasanti, } \\
\text { Cahyono, } \\
\text { and Astuti } \\
(2016)\end{array}$ & $\begin{array}{l}\text { secondary } \\
\text { school students }\end{array}$ & EFL & $\begin{array}{l}\text { The Flipped classroom model has significant effect on the } \\
\text { performance of the learners. }\end{array}$ \\
\hline $\begin{array}{l}\text { Alsancak } \\
\text { Sirakaya and } \\
\text { Ozdemir } \\
(2018)\end{array}$ & $\begin{array}{l}\text { Undergraduate } \\
\text { students }\end{array}$ & $\begin{array}{l}\text { Scientific } \\
\text { Research } \\
\text { Methods" course }\end{array}$ & $\begin{array}{l}\text { The Flipped classroom model produced significance } \\
\text { difference in student's engagement, academic } \\
\text { achievement and participation as compared to the } \\
\text { traditional lecture method. }\end{array}$ \\
\hline $\begin{array}{l}\text { Nielsen, } \\
\text { Bean, and } \\
\text { Larsen } \\
(2018)\end{array}$ & $\begin{array}{l}\text { Undergraduate } \\
\text { students }\end{array}$ & Statistics Course & $\begin{array}{l}\text { The outcomes showed a statistically significant } \\
\text { enhancement in the students' academic performance and } \\
\text { courses satisfaction with Flipped classroom model. }\end{array}$ \\
\hline $\begin{array}{l}\mathrm{Li} \quad \text { and } \\
\text { Suwanthep } \\
(2017)\end{array}$ & $\begin{array}{ll}\text { First } & \text { year } \\
\text { students }\end{array}$ & English & $\begin{array}{l}\text { The results of the study concluded that Flipped } \\
\text { classroom model had increased the students' academic } \\
\text { and comprehension skills as compared to the traditional } \\
\text { lecture method. }\end{array}$ \\
\hline $\begin{array}{l}\text { Aşsksoy and } \\
\text { Özdamlı } \\
(2016)\end{array}$ & $\begin{array}{l}\text { Undergraduate } \\
\text { students }\end{array}$ & physics course & $\begin{array}{l}\text { The students in experimental group learnt by Flipped } \\
\text { classroom model had performed better as compared to } \\
\text { the control group learnt by traditional lecture method. }\end{array}$ \\
\hline $\begin{array}{l}\text { Esperanza, } \\
\text { Fabian, and } \\
\text { Toto }(2016)\end{array}$ & $\begin{array}{l}\text { High school } \\
\text { student }\end{array}$ & $\begin{array}{l}\text { Algebra } \\
\text { Mathematics }\end{array}$ & Flipped classroom model produced significant results. \\
\hline $\begin{array}{l}\text { Tsai, Shen, } \\
\text { and } \quad \text { Lu } \\
(2015)\end{array}$ & $\begin{array}{l}\text { elementary } \\
\text { school students }\end{array}$ & $\begin{array}{l}\text { Production of E- } \\
\text { book course }\end{array}$ & $\begin{array}{l}\text { It is resulted that the impact of Flipped classroom model } \\
\text { on students learning abilities was statistically significant } \\
\text { than the traditional lecture method. }\end{array}$ \\
\hline $\begin{array}{l}\text { Turan and } \\
\text { Goktas } \\
(2016)\end{array}$ & $\begin{array}{l}\text { first-year } \\
\text { students }\end{array}$ & computer & $\begin{array}{l}\text { The results of the study concluded that the courses } \\
\text { taught with Flipped classroom model of instruction had } \\
\text { better academic achievements as compared to the } \\
\text { traditional lecture method. The flipped classroom model } \\
\text { had also improved the cognitive ability of the learners. }\end{array}$ \\
\hline $\begin{array}{l}\text { Bhagat, } \\
\text { Chang, and } \\
\text { Chang } \\
(2016)\end{array}$ & $\begin{array}{l}\text { high-school } \\
\text { students }\end{array}$ & trigonometry & $\begin{array}{l}\text { The conclusion of the research indicated that there was a } \\
\text { significant difference in the students' academic } \\
\text { achievement and motivation. The learners learnt by } \\
\text { Flipped classroom model achieved better results as } \\
\text { compared to the traditional lecture method. }\end{array}$ \\
\hline $\begin{array}{l}\text { Bachelor } \\
(2017) \\
\end{array}$ & K-12 & SPAN 101 course & $\begin{array}{l}\text { On the basis of results, there were no significant } \\
\text { differences found between flipped classroom model and } \\
\text { traditional lecture method. }\end{array}$ \\
\hline
\end{tabular}




\begin{tabular}{|c|c|c|c|}
\hline $\begin{array}{l}\text { Shiau et al. } \\
(2018)\end{array}$ & $\begin{array}{l}\text { Masters-level } \\
\text { students }\end{array}$ & Epidemiology & $\begin{array}{l}\text { No significant differences were found in the scores by } \\
\text { Flipped classroom model and traditional lecture method. }\end{array}$ \\
\hline $\begin{array}{l}\text { Alsowat } \\
(2016)\end{array}$ & $\begin{array}{l}\text { Graduate } \\
\text { students }\end{array}$ & English & $\begin{array}{l}\text { The results of the research revealed that there was a } \\
\text { significant difference between two groups taught by } \\
\text { Flipped classroom model and traditional lecture method. } \\
\text { The flipped classroom model also increased the higher } \\
\text { order thinking skills of learners. }\end{array}$ \\
\hline Kurt (2017) & $\begin{array}{l}\text { College } \\
\text { students }\end{array}$ & $\begin{array}{l}\text { classroom } \\
\text { management } \\
\text { course }\end{array}$ & $\begin{array}{l}\text { Conclusions showed a higher level of thinking skills by } \\
\text { Flipped classroom model as compared to the traditional } \\
\text { lecture method. }\end{array}$ \\
\hline $\begin{array}{lr}\text { Perera } & \text { and } \\
\text { de } & \text { Silva } \\
(2017) & \end{array}$ & $\begin{array}{l}\text { Undergraduates } \\
\text { students }\end{array}$ & $\begin{array}{l}\text { Clinical } \\
\text { Microbiology }\end{array}$ & $\begin{array}{l}\text { The results of the study indicated that Flipped classroom } \\
\text { model was proved better than the traditional lecture } \\
\text { method. }\end{array}$ \\
\hline $\begin{array}{l}\text { Kazanidis, } \\
\text { Pellas, } \\
\text { Fotaris, and } \\
\text { Tsinakos } \\
(2019)\end{array}$ & $\begin{array}{l}\text { Undergraduate } \\
\text { students }\end{array}$ & $\begin{array}{l}\text { Media Design } \\
\text { subjects }\end{array}$ & $\begin{array}{l}\text { The study findings indicated that the students in the } \\
\text { experimental group performed significantly better. }\end{array}$ \\
\hline
\end{tabular}

Table-4. Statistical Results of the Studies Reviewed in this Article at a Significance level of 0.05.

\begin{tabular}{|c|c|c|c|c|c|}
\hline Reference & Method & Mean & SD & p & Remarks \\
\hline \multirow[t]{2}{*}{ Pierce et al. (2012) } & Traditional & 77.7 & 4.7 & \multirow[b]{2}{*}{0.024} & \multirow[b]{2}{*}{ Significant } \\
\hline & Flipped & 81.6 & 4.4 & & \\
\hline \multirow[t]{2}{*}{ Tune et al. (2013) } & Traditional & 64 & 3.67 & \multirow[b]{2}{*}{0.002} & \multirow[b]{2}{*}{ Significant } \\
\hline & Flipped & 68 & 3.47 & & \\
\hline \multirow[b]{2}{*}{ Cabı (2018) } & Traditional & 56.64 & 1.42 & \multirow[b]{2}{*}{0.478} & \multirow[b]{2}{*}{ Non-Significant } \\
\hline & Flipped & 55.29 & 1.61 & & \\
\hline \multirow[t]{2}{*}{ Keengwe (2014) } & Traditional & 2.80 & 1.00 & \multirow[b]{2}{*}{0.035} & \multirow[b]{2}{*}{ Significant } \\
\hline & Flipped & $\mathrm{M}=3.59$ & 0.98 & & \\
\hline \multirow[t]{2}{*}{ Overmyer (2014) } & Traditional & 21.27 & 5.130 & \multirow[b]{2}{*}{0.057} & \multirow[b]{2}{*}{ Non-Significant } \\
\hline & Flipped & 20.14 & 5.101 & & \\
\hline \multirow[b]{2}{*}{$\begin{array}{l}\text { Aidinopoulou and Sampson } \\
(2017)\end{array}$} & Traditional & 8.72 & 1.401 & \multirow[b]{2}{*}{0.690} & \multirow[b]{2}{*}{ Non-significant } \\
\hline & Flipped & 8.95 & 1.250 & & \\
\hline \multirow[t]{2}{*}{ Smallhorn (2017) } & Traditional & 58.52 & 19.96 & \multirow[b]{2}{*}{0.864} & \multirow[b]{2}{*}{ Non-Significant } \\
\hline & Flipped & 58.25 & 21.45 & & \\
\hline \multirow[t]{2}{*}{ Kostaris et al. (2017) } & Traditional & 15.825 & 1.827 & \multirow[b]{2}{*}{0.0146} & \multirow[b]{2}{*}{ Significant } \\
\hline & Flipped & 17.125 & 1.440 & & \\
\hline \multirow[t]{2}{*}{ Olakanmi (2017) } & Traditional & 1.41 & 3.68 & \multirow[b]{2}{*}{0.04} & \multirow[b]{2}{*}{ Significant } \\
\hline & Flipped & 5.70 & 3.58 & & \\
\hline \multirow[t]{2}{*}{ Nouri (2016) } & Traditional & 3.194 & 1.134 & & \\
\hline & Flipped & 3.409 & 1.118 & 0.023 & Significant \\
\hline & Traditional & 3.39 & 0.676 & & \\
\hline Morgan et al. (2015) & Flipped & 3.624 & 0.564 & 0.03 & Significant \\
\hline Ayçiçek and Yanpar Yelken & Traditional & 13.77 & 5.83 & 0.022 & \\
\hline$(2018)$ & Flipped & 15.28 & 5.57 & & Significant \\
\hline Ahmad (2016) & Traditional & 8.235 & 4.143 & & \\
\hline & Flipped & 7.559 & 3.886 & 0.025 & Significant \\
\hline Namaziandost and & Traditional & 23.41 & 2.984 & & \\
\hline$(2020)$ & Flipped & 25.43 & 2.756 & 0.037 & Significant \\
\hline Lee and Lai (2017) & Traditional & 3.72 & 0.827 & & \\
\hline & Flipped & 4.06 & 0.747 & 0.4095 & Non-Significant \\
\hline Gillispie (2016) & Traditional & 27.325 & 4.02 & & \\
\hline & Flipped & 28.65 & 3.79 & 0.4945 & Non-Significant \\
\hline Baytiyeh (2017) & Traditional & 77 & 13.8428 & & \\
\hline & Flipped & 79.428 & 4.9571 & 0.02 & Significant \\
\hline Afrilyasanti et al. (2016) & Traditional & 56.8 & 6.17 & & \\
\hline
\end{tabular}




\begin{tabular}{|c|c|c|c|c|c|}
\hline & Flipped & 66.495 & 5.66 & 0.0089 & Significant \\
\hline \multirow{2}{*}{$\begin{array}{l}\text { Alsancak Sirakaya and Ozdemir } \\
(2018)\end{array}$} & Traditional & 30.8 & 6.05 & \multirow[b]{2}{*}{0.045} & \multirow[b]{2}{*}{ Significant } \\
\hline & Flipped & 33.15 & 5.5 & & \\
\hline \multirow[t]{2}{*}{ Nielsen et al. (2018) } & Traditional & 26.41 & 4.09 & \multirow[b]{2}{*}{0.0475} & \multirow[b]{2}{*}{ Significant } \\
\hline & Flipped & 26.74 & 4.03 & & \\
\hline \multirow[t]{2}{*}{ Li and Suwanthep (2017) } & Traditional & 11.604 & 2.7335 & \multirow[b]{2}{*}{0.029} & \multirow[b]{2}{*}{ Significant } \\
\hline & Flipped & 12.3365 & 2.629 & & \\
\hline \multirow[t]{2}{*}{ Aşıksoy and Özdamlı (2016) } & Traditional & 62.12 & 2.906 & \multirow[b]{2}{*}{0.011} & \multirow[b]{2}{*}{ Significant } \\
\hline & Flipped & 74.63 & 1.949 & & \\
\hline \multirow[t]{2}{*}{ Esperanza et al. (2016) } & Traditional & 6.51 & 2.67 & \multirow[b]{2}{*}{0.0462} & \multirow[b]{2}{*}{ Significant } \\
\hline & Flipped & 5.93 & 2.18 & & \\
\hline \multirow[t]{2}{*}{ Tsai et al. (2015) } & Traditional & 92.79 & 3.009 & \multirow[b]{2}{*}{0.004} & \multirow[b]{2}{*}{ Significant } \\
\hline & Flipped & 94.36 & 2.202 & & \\
\hline \multirow{2}{*}{ Turan and Goktas (2016) } & Traditional & 67.01 & 2.43 & \multirow[b]{2}{*}{0.0148} & \multirow[b]{2}{*}{ Significant } \\
\hline & Flipped & 78.90 & 2.05 & & \\
\hline \multirow[t]{2}{*}{ Bhagat et al. (2016) } & Traditional & 8.966 & 2.228 & \multirow[b]{2}{*}{0.018} & \multirow[b]{2}{*}{ Significant } \\
\hline & Flipped & 9.735 & 1.628 & & \\
\hline \multirow[t]{2}{*}{ Bachelor (2017) } & Traditional & 68.935 & 26.495 & \multirow[b]{2}{*}{0.567} & \multirow[b]{2}{*}{ Non-Significant } \\
\hline & Flipped & 64.025 & 29.695 & & \\
\hline \multirow[t]{2}{*}{ Shiau et al. (2018) } & Traditional & 90.95 & 9.34 & \multirow[b]{2}{*}{0.385} & \\
\hline & Flipped & 92.3 & 6.475 & & Non-Significant \\
\hline Alsowat (2016) & Traditional & 7.617 & 1.95 & & \\
\hline & Flipped & 7.515 & 1.62 & 0.00816 & Significant \\
\hline Kurt (2017) & Traditional & 145.935 & 19.735 & & \\
\hline & Flipped & 143.86 & 24.165 & 0.10 & Non-Significant \\
\hline Perera and de Silva (2017) & Traditional & 5.4 & 2.6 & 0.0009 & Significant \\
\hline & Flipped & 6.85 & 1.9 & & \\
\hline Liebert, Lin, Mazer, Bereknyei, & Traditional & 75.8585 & 8.045 & & \\
\hline and Lau (2016) & Flipped & 74.881 & 8.03 & 0.337 & Non-Significant \\
\hline Albalawi (2018) & Traditional & 15.345 & 2.745 & & \\
\hline & Flipped & 19.848 & 1.8765 & 0.228 & Non-Significant \\
\hline Ramadhani, & Traditional & 68.1363 & 7.301 & & \\
\hline Abdurrahman, and Syazali (2019) & Flipped & 70.22 & 5.602 & 0.0085 & Significant \\
\hline Kazanidis et al. (2019) & Traditional & 49.3495 & 8.34 & & \\
\hline & Flipped & 52.261 & 8.95 & 0.0476 & Significant \\
\hline
\end{tabular}

The effectiveness of flipped classroom model of instruction has been proved by many studies including (Afzali \& Izadpanah, 2021; Bhat, Raju, Bhat, \& D’Souza, 2020; Enfield, 2013). The application of flipped classroom model of instruction as a substitute to the traditional learning settings has drawn the attention of instructors and researchers (Johnston, 2017). It is even asserted that the flipped classroom model, which is used to create effective teaching environments at schools, is the best model for adapting with technology (Hamdan, McKnight, McKnight, \& Arfstrom, 2013). Studies about the flipped classroom appear in different disciplines including information systems (Davies et al., 2014), engineering, sociology, and humanities (Kim, Kim, Khera, \& Getman, 2014) mathematics education (Zengin, 2017) and English composition (Zhonggen \& Guifang, 2016).

A review study has been conducted to compare the effectiveness of flipped classroom model of instruction and traditional lecture method. The review of literature and statistical results show that in most of the cases, flipped classroom strategy is very useful for the active learning, student's engagement, problem solving and students higher order thinking skills. However, there are number of results in which there was no significant difference between flipped classroom model and traditional lecture method has been found.

\section{CONCLUSION}

A critical comparison of Flipped classroom model and Traditional lecture method has been presented in this study. This comparative review shows that Flipped classroom model is an effective strategy for learning. It 
increases the self-efficacy of students in comparison with the Traditional lecture method. The main features of flipped classroom model of instruction presented in the literature are active learning method, group discussion, collaborations and problem-solving method. When statistical results are compared between 33 selected articles, the Flipped classroom model shows more significance value in 22 articles and no significance is found in 11 articles between Flipped classroom model and Traditional lecture method. So, it can be concluded that Flipped classroom model is more effective teaching strategy as related to the Traditional method of teaching.

\section{RECOMMENDATIONS}

In order to be consistent with the results of most of the literature reviewed in this article, the instructor should follow the flipped classroom learning strategy to achieve the high academic performance.

Funding: This study received no specific financial support.

Competing Interests: The authors declare that they have no competing interests.

Acknowledgement: All authors contributed equally to the conception and design of the study.

\section{REFERENCES}

Abedi, P., Keshmirshekan, M. H., \& Namaziandost, E. (2019). The comparative effect of flipped classroom instruction versus traditional instruction on Iranian intermediate EFL learners' English composition writing. Journal of Applied Linguistics and Language Research, 6(4), 43-56.

Abeysekera, L., \& Dawson, P. (2015). Motivation and cognitive load in the flipped classroom: definition, rationale and a call for research. Higher Education Research \& Development, 34(1), 1-14.Available at: https://doi.org/10.1080/07294360.2014.934336.

Afrilyasanti, R., Cahyono, B. Y., \& Astuti, U. P. (2016). Effect of flipped classroom model on Indonesian EFL students' writing ability across and individual differences in learning. International Journal of English Language and Linguistics Research, $4(5), 65-81$.

Afzali, Z., \& Izadpanah, S. (2021). The effect of the flipped classroom model on Iranian English foreign language learners: Engagement and motivation in English language grammar. Cogent Education, 8(1), 1870801.Available at: https://doi.org/10.1080/2331186x.2020.1870801.

Ahmad, S. Z. (2016). The flipped classroom model to develop Egyptian EFL students' listening comprehension. English Language Teaching, 9(9), 166-178.Available at: https://doi.org/10.5539/elt.v9n9p 166.

Aidinopoulou, V., \& Sampson, D. G. (2017). An action research study from implementing the flipped classroom model in primary school history teaching and learning. Journal of Educational Technology \& Society, 20(1), 237-247.Available at: https://www.jstor.org/stable/10.2307/jeductechsoci.20.1.237.

Albalawi, A. S. (2018). The effect of using flipped classroom in teaching calculus on students' achievements at University of Tabuk. International Journal of Research in Education and Science, 4(1), 198-207.Available at: https://doi.org/10.21890/ijres.383137.

Alsancak Sirakaya, D., \& Ozdemir, S. (2018). The effect of a flipped classroom model on academic achievement, self-directed learning readiness, motivation and retention. Malaysian Online Journal of Educational Technology, 6(1), 76-91.

Alsowat, H. (2016). An EFL flipped classroom teaching model: Effects on English language higher-order thinking skills, student engagement and satisfaction. Journal of Education and Practice, 7(9), 108-121.

Ash, K. (2012). Educators view flipped model with a more critical eye. Education Week, 32(2), S6-S7.

Aşıksoy, G., \& Özdaml, F. (2016). Flipped Classroom adapted to the ARCS Model of Motivation and applied to a Physics Course. Eurasia Journal of Mathematics, Science and Technology Education, 12(6), 1589-1603.Available at: https://doi.org/10.12973/eurasia.2016.1251a. 
Ayçiçek, B., \& Yanpar Yelken, T. (2018). The effect of flipped classroom model on students' classroom engagement in teaching English. International Journal of Instruction, 11(2), 385-398.Available at: https://doi.org/10.12973/iji.2018.11226a.

Bachelor, J. W. (2017). Increasing student communication and spontaneous language use in the L2 classroom: A careful consideration of the flipped classroom model. Online Submission, 6(3), 5-11.

Baytiyeh, H. (2017). The flipped classroom model: When technology enhances professional skills. International Journal of Information and Learning Technology, 34(1), 51-62.Available at: https://doi.org/10.1 108/ijilt-07-2016-0025.

Bergmann, J., \& Sams, A. (2012). Flip your classroom: Reach every student in every class every day in. Washington, DC: International Society for Technology in Education.

Bernard, J. S. (2015). The flipped classroom: fertile ground for nursing education research. International Journal of Nursing Education Scholarship, 12(1), 99-109.Available at: https://doi.org/10.1515/ijnes-2015-0005.

Bhagat, K. K., Chang, C.-N., \& Chang, C.-Y. (2016). The impact of the flipped classroom on mathematics concept learning in high school. Journal of Educational Technology \& Society, 19(3), 134-142.Available at: https://doi.org/10.21083/ajote.v9i2.6182.

Bhat, S., Raju, R., Bhat, S., \& D’Souza, R. (2020). Redefining quality in engineering education through the flipped classroom model. Procedia Computer Science, 172, 906-914.Available at: https://doi.org/10.1016/j.procs.2020.05.131.

Bishop, J. L., \& Verleger, M. A. (2013). The flipped classroom: A survey of the research. Paper presented at the ASEE National Conference Proceedings, Atlanta, GA.

Brunsell, E., \& Horejsi, M. (2013). A flipped classroom in action. The Science Teacher, 80(2), 8-17.

Buckman, S., Pijawka, D., Gomez, M., Davis, J., Opejin, A., \& Mahid, Y. (2010). Benefits of "Flip" teaching techniques in the environmental planning and sustainability classroom. Education, 2010.

Cabı, E. (2018). The impact of the flipped classroom model on students' academic achievement. International Review of Research in Open and Distributed Learning, 19(3), 201-221.Available at: https://doi.org/10.19173/irrodl.v 19i3.3482.

Chen, K.-S., Monrouxe, L., Lu, Y.-H., Jenq, C.-C., Chang, Y.-J., Chang, Y.-C., \& Chai, P. Y.-C. (2018). Academic outcomes of flipped classroom learning: A meta-analysis. Medical Education, 52(9), 910-924.

Davies, D., Jindal-Snape, D., Digby, R., Howe, A., Collier, C., \& Hay, P. (2014). The roles and development needs of teachers to promote creativity: A systematic review of literature. Teaching and Teacher Education, 41, 34-41.Available at: https://doi.org/10.1016/j.tate.2014.03.003.

Enfield, J. (2013). Looking at the impact of the flipped classroom model of instruction on undergraduate multimedia students at CSUN. TechTrends, 57(6), 14-27.Available at: https://doi.org/10.1007/s11528-013-0698-1.

Esperanza, P., Fabian, K., \& Toto, C. (2016). Flipped classroom model: effects on performance, attitudes and perceptions in high school algebra. In European Conference on Technology Enhanced Learning. Paper presented at the In European Conference on Technology Enhanced Learning. Springer, Cham.FL.

Gillette, C., Rudolph, M., Kimble, C., Rockich-Winston, N., Smith, L., \& Broedel-Zaugg, K. (2018). A meta-analysis of outcomes comparing flipped classroom and lecture. American Journal of Pharmaceutical Education, 82(5), 68-98.Available at: https://doi.org/10.5688/ajpe6898.

Gillispie, V. (2016). Using the flipped classroom to bridge the gap to generation Y. Ochsner Journal, 16(1), 32-36.

Graham, C. R., Woodfield, W., \& Harrison, J. B. (2013). A framework for institutional adoption and implementation of blended learning in higher education. The Internet and Higher Education, 18, 4-14.Available at: https://doi.org/10.1016/j.iheduc.2012.09.003.

Grant, C. (2013). First Inversion: A rationale for implementing the" Flipped Approach" in tertiary music courses. Australian Journal of Music Education, 1(2013), 3-12.

Hafeez, M., Kazmi, Q. A., Tahira, F., Zahid, M., Sajad, H., Yasmeen, A. A., .. Saqi, M. I. (2020). Impact of school enrolment size on student's achievements. Journal of Education, Humaniora and Social Sciences, 3(1), 26-30.Available at: https://doi.org/10.34007/jehss.v3i1.170. 
Hamdan, N., McKnight, P., McKnight, K., \& Arfstrom, K. M. (2013). The flipped learning model: A white paper based on the literature review titled "A review of flipped learning". Arlington, VA: Flipped Learning Network.

Hew, K. F., \& Lo, C. K. (2018). Flipped classroom improves student learning in health professions education: A meta-analysis. BMC Medical Education, 18(1), 1-12.Available at: https://doi.org/10.1186/s12909-018-1 144-z.

Janotha, B. (2016). Improving student achievement with flipped classroom pedagogy. Paper presented at the Nursing Research.

Johnston, B. M. (2017). Implementing a flipped classroom approach in a university numerical methods mathematics course. International Journal of Mathematical Education in Science and Technology, 48(4), 485-498.Available at: https://doi.org/10.1080/0020739x.2016.1259516.

Kazanidis, I., Pellas, N., Fotaris, P., \& Tsinakos, A. (2019). Can the flipped classroom model improve students' academic performance and training satisfaction in Higher Education instructional media design courses? British Journal of Educational Technology, 50(4), 2014-2027.Available at: https://doi.org/10.1111/bjet.12694.

Keengwe, J. (2014). Promoting active learning through the flipped classroom model: IGI Global.

Keengwe, J., \& Bhargava, M. (2014). Mobile learning and integration of mobile technologies in education. Education and Information Technologies, 19(4), 737-746.Available at: https://doi.org/10.1007/s10639-013-9250-3.

Kim, M. K., Kim, S. M., Khera, O., \& Getman, J. (2014). The experience of three flipped classrooms in an urban university: An exploration of design principles. The Internet and Higher Education, 22, 37-50.Available at: https://doi.org/10.1016/j.iheduc.2014.04.003.

Kim, S., Jin, M., \& Lim, K. Y. (2015). Research Trends on Flipped Learning in South Korea. In S. Carliner, C. Fulford $\Theta^{2} N$. Ostasherwski (Eds.). Paper presented at the Proceedings of EdMedia 2015--World Conference on Educational Media and Technology. Montreal, Quebec, Canada: Association for the Advancement of Computing in Education (AACE).

Kostaris, C., Stylianos, S., Sampson, D. G., Giannakos, M., \& Pelliccione, L. (2017). Investigating the potential of the flipped classroom model in K-12 ICT teaching and learning: An action research study. International Forum of Educational Technology and Society, 20(1), 261-273.

Kurt, G. (2017). Implementing the flipped classroom in teacher education: Evidence from Turkey. Journal of Educational Technology \& Society, 20(1), $211-221$.

Lai, C.-L., \& Hwang, G.-J. (2016). A self-regulated flipped classroom approach to improving students' learning performance in a mathematics course. Computers \& Education, 100(September), 126-140.Available at: https://doi.org/10.1016/j.compedu.2016.05.006.

Lee, K.-y., \& Lai, Y.-c. (2017). Facilitating higher-order thinking with the flipped classroom model: A student teacher's experience in a Hong Kong secondary school. Research and Practice in Technology Enhanced Learning, 12(1), 821.Available at: https://doi.org/10.1186/s41039-017-0048-6.

Lewis, C. E., Chen, D. C., \& Relan, A. (2018). Implementation of a flipped classroom approach to promote active learning in the third-year surgery clerkship. The American Journal of Surgery, 215(2), 298-303.Available at: https://doi.org/10.1016/j.amjsurg.2017.08.050.

Li, S., \& Suwanthep, J. (2017). Integration of flipped classroom model for EFL speaking. International Journal of Learning and Teaching, 3(2), 118-123.

Liebert, C. A., Lin, D. T., Mazer, L. M., Bereknyei, S., \& Lau, J. N. (2016). Effectiveness of the surgery core clerkship flipped classroom: A prospective cohort trial. The American Journal of Surgery, 211(2), 451-457. e451.Available at: https://doi.org/10.1016/j.amjsurg.2015.10.004.

Michel, N., Cater III, J. J., \& Varela, O. (2009). Active versus passive teaching styles: An empirical study of student learning outcomes. Human Resource Development Quarterly, 20(4), 397-418.Available at: https://doi.org/10.1002/hrdq.20025.

Miles, C. A., \& Fogget, K. (2016). Supporting our students to achieve academic success in the unfamiliar world of flipped and blended classrooms. Journal of University Teaching and Learning Practice, 13(4), 2-15. 
Missildine, K., Fountain, R., Summers, L., \& Gosselin, K. (2013). Flipping the classroom to improve student performance and satisfaction. Journal of Nursing Education, 52(10), 597-599.Available at: https://doi.org/10.3928/01484834-2013091903.

Morgan, H., McLean, K., Chapman, C., Fitzgerald, J., Yousuf, A., \& Hammoud, M. (2015). The flipped classroom for medical students. The Clinical Teacher, 12(3), 155-160.

Namaziandost, E., \& Cakmak, F. (2020). An account of EFL learners' self-efficacy and gender in the flipped classroom model. Education and Information Technologies, 13(4), 1-15.

Nielsen, P. L., Bean, N. W., \& Larsen, R. A. A. (2018). The impact of a flipped classroom model of learning on a large undergraduate statistics class. Statistics Education Research Journal, 17(1), 121-140.

Nouri, J. (2016). The flipped classroom: for active, effective and increased learning-especially for low achievers. International Journal of Educational Technology in Higher Education, 13(1), 13-33.

O'Flaherty, J., \& Phillips, C. (2015). The use of flipped classrooms in higher education: A scoping review. The Internet and Higher Education, 25, 85-95.Available at: https://doi.org/10.1016/j.iheduc.2015.02.002.

Olakanmi, E. E. (2017). The effects of a flipped classroom model of instruction on students' performance and attitudes towards chemistry. Journal of Science Education and Technology, 26(1), 127-137.Available at: org/10.1109/fie.2009.53506 21.

Overmyer, G. R. (2014). The flipped classroom model for college algebra: Effects on student achievement. Doctoral Dissertation, Colorado State University.

Park, E. O., \& Park, J. H. (2018). Quasi-experimental study on the effectiveness of a flipped classroom for teaching adult health nursing. Japan Journal of Nursing Science, 15(2), 125-134.Available at: https://doi.org/10.1111/jjns. 12176.

Perera, V., \& de Silva, N. (2017). Flipped classroom model for teaching and learning medical microbiology. The Asia Pacific Scholar, 2(2), 24-29.

Pierce, R., Fox, J., \& Dunn, B. (2012). Instructional design and assessment: Vodcasts and active-learning exercises in a "flipped classroom" model of a renal pharmacotherapy module. American journal of pharmaceutical education, 76(10), 1-5.Available at: https://doi.org/10.5688/ajpe7610196.

Pohl, D., Bouchachia, A., \& Hellwagner, H. (2018). Batch-based active learning: Application to social media data for crisis management. Expert Systems with Applications, 93, 232-244.Available at: https://doi.org/10.1016/j.eswa.2017.10.026.

Ramadhani, R., Umam, R., Abdurrahman, A., \& Syazali, M. (2019). The effect of flipped-problem based learning model integrated with LMS-google classroom for senior high school students. Journal for the Education of Gifted Young Scientists, 7(2), 137-158.

Roach, T. (2014). Student perceptions toward flipped learning: New methods to increase interaction and active learning in economics. International Review of Economics Education, 17, 74-84.Available at: https://doi.org/10.1016/j.iree.2014.08.003.

Roehl, A., Reddy, S. L., \& Shannon, G. J. (2013). The flipped classroom: An opportunity to engage millennial students through active learning strategies. Journal of Family \& Consumer Sciences, 105(2), 44-49.Available at: https://doi.org/10.14307/jfcs 105.2.12.

Sezer, R. (2010). Pulling out all the stops. Education, 130(3), 416-424.

Shakibaei, G., Namaziandost, E., \& Shahamat, F. (2019). The effect of using authentic texts on Iranian EFL learners' incidental vocabulary learning: The case of English newspaper. International Journal of Linguistics, Literature and Translation (IJLLT), 2(5), 290395.

Shiau, S., Kahn, L. G., Platt, J., Li, C., Guzman, J. T., Kornhauser, Z. G., . . Martins, S. S. (2018). Evaluation of a flipped classroom approach to learning introductory epidemiology. BMC Medical Education, 18(1), 1-8.

Smallhorn, M. (2017). The flipped classroom: A learning model to increase student engagement not academic achievement. Student Success, 8(2), 43-53.Available at: 10.5204/ssj.v8i2.381. 
Sohrabi, B., \& Iraj, H. (2016). Implementing flipped classroom using digital media: A comparison of two demographically different groups perceptions. Computers in Human Behavior, 60, 514-524.Available at: https://doi.org/10.1016/j.chb.2016.02.056.

Staker, H., \& Horn, M. B. (2012). Classifying K-12 blended learning: Innosight Institute.

Toppo, G. (2011). Flipped' classrooms take advantage of technology: USA Today.

Tsai, C.-W., Shen, P.-D., \& Lu, Y.-J. (2015). The effects of problem-Based Learning with flipped classroom on elementary students' computing skills: A case study of the production of Ebooks. International Journal of Information and Communication Technology Education (IJICTE), $11(2)$, 32-40.

Tune, J., Sturek, M., \& Basile, D. (2013). The inverted classroom model improves the performance of graduate students in cardiovascular, respiratory and renal physiology. American Journal of Physiology - Advances in Physiology Teaching, 37(4), 316-320.

Turan, Z., \& Goktas, Y. (2016). The flipped classroom: instructional efficency and impact of achievement and cognitive load levels. Journal of E-learning and Knowledge Society, 12(4), 51-62.

Wilson, K. (2020). What does it mean to do teaching? A qualitative study of resistance to Flipped Learning in a higher education context. Teaching in Higher Education, 23(4), 1-14.

Zengin, Y. (2017). Investigating the use of the Khan academy and mathematics software with a flipped classroom approach in mathematics teaching. Journal of Educational Technology \& Society, 20(2), 89-100.

Zhonggen, Y., \& Guifang, W. (2016). Academic achievements and satisfaction of the clicker-aided flipped business English writing class. Journal of Educational Technology \& Society, 19(2), 298-312.

Views and opinions expressed in this article are the views and opinions of the author(s), International Journal of Education and Practice shall not be responsible or answerable for any loss, damage or liability etc. caused in relation to/arising out of the use of the content. 